\title{
Orthostatic proteinuria revisited: new clinical impact of the "old" clinical entity?
}

\author{
Hiroshi Tanaka ${ }^{1,2}$ \\ ${ }^{1}$ Department of School Health Science, Hirosaki University Faculty of Education, Hirosaki, Japan; ${ }^{2}$ Department of Pediatrics, Hirosaki University \\ Hospital, Hirosaki, Japan \\ Correspondence to: Hiroshi Tanaka, MD, PhD. Department of School Health Science, Hirosaki University Faculty of Education, Hirosaki, 036-8560 \\ Japan. Email: hirotana@hirosaki-u.ac.jp. \\ Provenance and Peer Review: This article was commissioned by the editorial office, Annals of Translational Medicine. The article did not undergo \\ external peer review. \\ Comment on: Niu XL, Wu Y, Hao S, et al. Value of micro-proteinuria in combination with ultrasonography of the left renal vein in the diagnosis of \\ orthostatic proteinuria. Ann Transl Med 2019;7:780.
}

Submitted Feb 12, 2020. Accepted for publication Feb 19, 2020.

doi: $10.21037 /$ atm.2020.02.181

View this article at: http://dx.doi.org/10.21037/atm.2020.02.181

Orthostatic proteinuria $(\mathrm{OP})$ is a clinical entity that has been encountered in daily clinical practice since approximately $>35$ years ago $(1,2)$. In general, OP is defined as the appearance of significant proteinuria while in the upright or lordotic position, but not in the recumbent position, in healthy individuals without kidney diseases. Its long-term outcome is usually good $(1,2)$. The postulated prevalence of $\mathrm{OP}$ is not rare in children and adolescents (for approximately $>10 \%$ in asymptomatic proteinuria (3); it is occasionally encountered even in adults, particularly those with low body mass indexes (BMIs) $(4,5)$. Although the etiology of OP remains unclear, probable renal congestion due to the left renal vein entrapment phenomenon (left renal vein entrapment syndrome or nutcracker syndrome) is attributable to the transient increase in the permeability of the glomerular filtration barrier that leads to the appearance of proteinuria (6). As low BMI that results in a narrow space between the aorta and the superior mesenteric artery is the main cause of the nutcracker syndrome in children and adolescents, low BMI is thought to modulate $\mathrm{OP}$ as well $(3-5,7)$. The nutcracker syndrome usually resolves with time; a correlation between increased BMI and growth, body weight gain, and regression of urinary abnormalities is apparent $(8,9)$. Thus, most cases of OP tend to show spontaneous remission with time and have a favorable long-term prognosis $(1,2)$. However, no validated clinical diagnostic index for differential diagnosis of OP and glomerulonephritis (GN) has been established to date
(10-12). OP is not a new clinical entity but still lacks clear definitive diagnostic criteria.

In this context, Niu et al. recently reported something new aspects of the clinical diagnostic criteria of OP in this journal (13). They examined the measurement parameters of microproteinuria such as urinary ratios of albumin to creatinine (Alb/Cr), IgG to creatinine (IgG/ $\mathrm{Cr}$ ), $\mathrm{N}$-acetyl- $\beta$-D-glucosaminidase to creatinine (NAG/ $\mathrm{Cr})$ and $\alpha 1$-microglobulin to creatinine $(\alpha 1 \mathrm{Mu} / \mathrm{Cr})$ with ultrasonography (USG) of the left renal vein (LRV) in 60 "strictly chosen" patients with OP (median age at onset, $10.6 \pm 2.8$ years) at rest and after activity to determine whether changes in these parameters could help in preliminary screening for OP in patients with suspected OP. When compared with the 15 controls without OP (median age, $10.9 \pm 3.3$ years), patients with $\mathrm{OP}$ had significantly increased urinary alb/Cr and $\mathrm{IgG} / \mathrm{Cr}$ after activity. Furthermore, they examined the area under the curve (AUC) of the parameters and found their best cutoff values with high sensitivity and specificity (13). They concluded that measurement of microproteinuria, especially urinary alb/Cr and $\mathrm{IgG} / \mathrm{Cr}$, in combination with USG of the LRV, is useful for the screening of OP in patients with asymptomatic proteinuria (13). Notably, their study participants underwent all the following three physiological tests for OP: the West test, the urine samples were collected both in the morning and after 2-3 hours of activity; upright lordotic posture test, the urine samples were collected before and 
Table 1 Representative published reports of urinary measurement parameters for differential diagnosis of orthostatic proteinuria from glomerulonephritis

\begin{tabular}{|c|c|c|c|c|c|c|}
\hline Authors (Ref.) & $\begin{array}{l}\text { Number of Study } \\
\text { participants }\end{array}$ & $\begin{array}{c}\text { Mean age } \\
\text { of study } \\
\text { participants }\end{array}$ & $\begin{array}{l}\text { Mean body mass } \\
\text { index }\end{array}$ & $\begin{array}{c}\text { Diagnostic rationale of } \\
\text { OP }\end{array}$ & $\begin{array}{l}\text { Performance of } \\
\text { USG of the LRV }\end{array}$ & $\begin{array}{l}\text { Significant urinary } \\
\text { parameters }\end{array}$ \\
\hline Ohshima (10) & $\begin{array}{c}\text { Glomerulonephritis, } \\
9\end{array}$ & $13.0 \pm 1.4$ years & Not described & & & \\
\hline Jin et al. (11) & $\begin{array}{l}\text { Glomerulonephritis, } \\
35\end{array}$ & $\begin{array}{c}26.5 \pm 10.7 \\
\text { years }\end{array}$ & $19.8 \pm 2.6 \mathrm{~kg} / \mathrm{m}^{2}$ & & & \\
\hline Kanai et al. (12) & $\begin{array}{c}\text { Orthostatic } \\
\text { proteinuria, } 16\end{array}$ & 12.8 years & Not described & $\begin{array}{c}\text { The upright lordotic } \\
\text { posture test }\end{array}$ & Not performed & FDP to creatinine ratio \\
\hline \multirow[t]{2}{*}{ Niu et al. (13) } & $\begin{array}{c}\text { Orthostatic } \\
\text { proteinuria, } 60\end{array}$ & $10.6 \pm 2.8$ years & $17.1 \pm 2.7 \mathrm{~kg} / \mathrm{m}^{2}$ & $\begin{array}{c}\text { The upright lordotic } \\
\text { posture test }\end{array}$ & $\begin{array}{l}\text { All the study } \\
\text { participants }\end{array}$ & $\begin{array}{l}\text { albumin to creatine } \\
\text { ratio and }\end{array}$ \\
\hline & $\begin{array}{l}\text { Glomerulonephritis, } \\
15\end{array}$ & $10.9 \pm 3.3$ years & $19.2 \pm 4.7 \mathrm{~kg} / \mathrm{m}^{2}$ & $\begin{array}{l}\text { Plus the West and } \\
\text { Robinson test }\end{array}$ & & IgG to creatinine ratio \\
\hline
\end{tabular}

USG, ultrasonography; LRV, left renal vein; FDP, fibrin/fibrinogen degradation products.

after the 15-minute upright lordotic posture; and Robinson test, sequential urine sample collection in the morning and after the hourly activity under dry food intake and fluid intake restrictions. Thus, participants were "strictly chosen" for this study. Given the remarkable patient selection, Niu et al. focused on the new impact of OP as an "old" clinical entity (13).

To date, some interesting papers that aimed to identify urinary simple biomarkers of OP to determine their diagnostic values have been published $(10,12)$. Previously, Ohshima reported that the ratio of urinary $\mathrm{IgG} / \mathrm{IgA}$ and serum IgG/IgA were significantly decreased in patients with GN than that in patients with OP (10). However, the sample size remained low $(n=14)$ and the diagnosis of OP depended only on the upright lordotic posture test result. Recently, Kanai et al. reported that the urinary fibrin/ fibrinogen degradation products (FDP) obtained in the upright position was significantly increased in patients with OP than in patients with GN (12). They concluded that the urinary FDP/Cr ratio showed high sensitivity and specificity in differentiating OP from active GN in either supine or upright position (12). However, the number of subjects was less $(n=16)$ and the diagnosis of OP depended only on the upright lordotic posture test result. Thus, compared with that in the previously published articles, Niu et al.'s sample size may be sufficient enough for drawing definitive conclusion. These issues are summarized in Table 1.

$\mathrm{OP}$ is considered a clinical entity with benign asymptomatic proteinuria particularly in children and adolescents $(1,2)$. Low BMI leading to a narrow space between the aorta and the superior mesenteric artery may modulate OP (3-6). On the contrary, some validated diagnostic criteria for OP remain to be studied. In this context, the measurement parameters of microproteinuria, especially urinary alb/Cr and $\mathrm{IgG} / \mathrm{Cr}$, in combination with USG of the LRV may be useful for screening of OP in patients with asymptomatic proteinuria. However, further studies are warranted.

\section{Acknowledgments}

Funding: None.

\section{Footnote}

Conflicts of Interest: The author has completed the ICMJE 
uniform disclosure form (available at http://dx.doi. org/10.21037/atm.2020.02.181). The author has no conflicts of interest to declare.

Ethical Statement: The author is accountable for all aspects of the work in ensuring that questions related to the accuracy or integrity of any part of the work are appropriately investigated and resolved.

Open Access Statement: This is an Open Access article distributed in accordance with the Creative Commons Attribution-NonCommercial-NoDerivs 4.0 International License (CC BY-NC-ND 4.0), which permits the noncommercial replication and distribution of the article with the strict proviso that no changes or edits are made and the original work is properly cited (including links to both the formal publication through the relevant DOI and the license). See: https://creativecommons.org/licenses/by-nc-nd/4.0/.

\section{References}

1. Vehaskari VM. Orthostatic proteinuria. Arch Dis Child 1982;57:729-30.

2. Leung AK, Wong AH. Proteinuria in children. Am Fam Physician 2010;82:645-51.

3. Tanaka H. High prevalence of underlying orthostatic proteinuria in young Japanese women. Pediatr Int 2019;61:306-7.

4. Milani G, Bianchetti MG, Bozzani S, et al. Body mass index modulates postural proteinuria. Int Urol Nephrol 2010;42:513-5.

5. Uehara K, Tominaga N, Shibagaki Y. Adult orthostatic

Cite this article as: Tanaka $\mathrm{H}$. Orthostatic proteinuria revisited: new clinical impact of the "old" clinical entity? Ann Transl Med 2020;8(13):814. doi: 10.21037/atm.2020.02.181 proteinuria. Clin Kidney J 2014;7:327-8.

6. Mazzoni MBM, Kottanatu L, Simonetti GD, et al. Renal vein obstruction and orthostatic proteinuria: a review. Nephrol Dial Transplant 2011;26:562-5.

7. Sato Y, Fujimoto S, Konta T, et al. U-shaped association between body mass index and proteinuria in a large Japanese general population sample. Clin Exp Nephrol 2014;18:75-86.

8. Tanaka H, Waga S. Spontaneous remission of persistent severe hematuria in an adolescent with nutcracker syndrome: A seven years' observation. Clin Exp Nephrol 2004;8:68-70.

9. Alaygut D, Bayram M, Soylu A, et al. Clinical course of children with nutcracker syndrome. Urology 2013;82:686-90.

10. Ohshima T. Studies on urinary protein component in renal disease in children, II: Comparison between children with orthostatic proteinuria and children with remission of glomerulonephritis (in Japanese). Nippon Zinzo Gakkai Shi (Jpn J Nephrol) 1994;36:1137-44.

11. Jin M, Hu P, Ding R, et al. Effectiveness of supine/ standing urinalysis for differential diagnosis of left renal vein entrapment syndrome combined with or without glomerulopathy. Nephrology (Carlton) 2014;19:332-8.

12. Kanai H, Sawanobori E, Kobayashi A, et al. Urinary fibrin/fibrinogen degradation products measured using an anti-fibrinogen antibody predict orthostatic proteinuria. Pediatr Int 2018;60:639-44.

13. Niu XL, Wu Y, Hao S, et al. Value of microproteinuria in combination with ultrasonography of the left renal vein in the diagnosis of orthostatic proteinuria. Ann Transl Med 2019;7:780. 